\title{
PRIVATE EQUITY NA CARTEIRA DE INVESTIMENTOS DAS ENTIDADES DE PREVIDÊNCIA PRIVADA
}

ALEXSANDRO BROEDEL LOPES

Professor Associado e Livre-Docente do Departámento de Contabilidade e Atuária da Faculdade de Economia. Administração e Contabilidade da Universidade de Sáo Paulo - Campus Capital

Bolsista do CNPq

E-mail: broedel@usp.br
CLÁUDIO VILAR FURTADO

Professor Doutor e Coordenador do Centro de Estudos em Private Equity da Escola de Administraçáo de Empresas de Sáo Paulo da Fundaçăo Getúlio Vargas - SP

E-mail: cvf@cvt.com.br

\section{RESUMO}

Este trabalho visa examinar e discutir o investimento em cotas de fundos de private equity, venture capital e mezaninos, denominados pela legislação recente, no Brasil, de fundos de investimento em participações e em empresas emergentes (FIPs e FIEEs), nos investimentos de entidades de previdência complementar, considerando as características singulares dessa classe de investimentos alternativos (carteira de participações).

Palavras-chave: Private Equity, Venture Capital, Alm, Investimentos, Governança.

\section{ESCOPO E JUSTIFICATIVA DO TRABALHO}

Os fundos de private equity e venture capital constituem veículos de investimento bastante consolidados nos Estados Unidos e Comunidade Européia (principalmente Inglaterra) onde, ao fim de mais de cinqüenta anos de existência, movimentam recursos da ordem de 70 bilhões de dólares anualmente (dados do período de 19982003).

No Brasil, a indústria de private equity e venture capital encontra-se, ainda, em seu primeiro ciclo, dado que o maior número de fundos e gestores, principalmente de origem estrangeira, foi constituído após 1995.

Este trabalho introduz as características singulares dessa categoria de investimentos e examina as melhores práticas internacionais de alocação de investimentos, seleção, monitoramente e política de incentivos aos gestores, de modo a orientar os vários interessados e chamar a atenção dos formuladores de políticas públicas para a importância da consolidação desses veículos de financiamento privado no desenvolvimento do setor produtivo nacional.

O foco do trabalho é, eminentemente, técnico pelo que não se adota o ponto de vista desse ou daquele agente econômico. Seu principal objetivo é comunicar a intuiçăo econômica que permeia os investimentos nessa classe de ativos, evitando-se oferecer provas matemáticas analíticas. Não se trata de um tratado definitivo sobre 0 assunto, mas procura-se suscitar a discussão e o debate em torno do tema.

Os temas aqui apresentados foram escolhidos por intermédio de pesquisas realizadas pelos autores e de discussōes com gestores e investidares que participam dessa indústria no Brasil. Optou-se por analisar os seguintes aspectos dessa classe de ativos no Brasil:

Justificativa econômica:

1. Impacto potencial do investimento nessa categoria de ativos private equity na carteira total de ativos geridos pelas Entidades de Previdência Complementar;

2. Exame preliminar da problemática de alternativas existentes sobre Contabilização e Valoraçâo das Cotas dos Fundos de Investimento em Participações e 
3. Seleção, monitoramento e política de incentivos aos Gestores de Fundos de Private Equity e Venture Capital: a governança no processo de gestão dos fundos.

\section{O NEXO DO INVESTIMENTO DAS EFPCS NAS CATEGORIAS DE PRIVATE EQUITY, VENTURE CAPITAL E MEZANINOS (FIPS E FIEES) DA CARTEIRA DE PARTICIPAÇÕES}

A literatura tradicional de investimentos mostra que o tema de alocação intertemporal de recursos é, também. central na discussão econômica: ela reside na determinação da perda marginal de utilidade por parte do agente econômico investidor ao abrir mão do consumo imediatamente. Essa perda marginal deve, no máximo, igualar a utilidade do ganho marginal de se consumir um pouco mais no futuro.

Esse princípio, relativamente simples, guarda a essência do funcionamento das economias capitalistas modernas: os detentores de recursos para a realização de investimento devem direcioná-los para as alternativas de investimento que apresentarem maior ganho marginal.

O bom funcionamento desse fluxo de recursos das unidades econômicas superavitárias (investidores) para as unidades econômicas deficitárias (oportunidades de negócio) produz importantes impactos na economia. Esse funcionamento garante que as melhores oportunidades de investimento poderão competir igualmente por recursos de forma que as mais atrativas acabarão por ser realizadas. Esse mecanismo de controle de mercado otimiza o processo de alocação intertemporal de recursos e conseqüentemente a criação de valor para toda a sociedade.

Existem vários veículos no mercado financeiro para que esse fluxo da poupança ao investimento possa ser realizado, incluindo os FIPs e FIEEs. Os intermediários financeiros (Bancos, Seguradoras, Fundos de Investimento etc.) procuram casar os interesses de investidores (poupadores) e dos tomadores de recursos para investimentos. São, da mesma forma, importantes os intermediários de informações (agências de rating, auditores, analistas de mercado de capitais etc) que buscam quebrar a assimetria informacional entre os detentores de capital (investidores) e os gestores das oportunidades de investimento.

Parece haver consenso entre os economistas de que o bom funcionamento do mercado financeiro é condiçāo sine qua non para o desenvolvimento econômico. Países desenvolvidos, normalmente, possuem mecanismos eficientes de alocaçāo de ativos dentro do modelo de financiamento via mercado público de títulos e valores mobiliários ou via financiamento dentro do insider model'. Se esses modelos existem com relativo sucesso internacional, de onde surge a demanda por investimentos em private equity? Ela surge, justamente, de algumas características de funcionamento do mercado público de títulos e valores mobiliários como será visto a seguir.

Pode-se caracterizar o investimento de private equity, venture capital, mezanino e pipes - private investment in public equity (serão denominados Fundos de PENC de agora em diante para usar a expressão mais conhecida internacionalmente) como participaçōes privadas de longo prazo de maturação, exercidas em empresas de capital fechado ou aberto, acompanhadas de um processo de participação na gestão do empreendimento ou de seu monitoramento, adquiridas por meio de negociaçōes privadas. Outra importante característica desse investimento é sua orientaçāo para o desinvestir (exit) em prazos longos que costumam ser inferiores a 7 anos nos Estados Unidos, podendo chegar a mais de 15 anos no Japão.

Consistente com sua característica básica, as negociações para a obtenção dos direitos sobre o negócio são feitas de forma privada não passando pelos recintos tradicionais como Bolsas de Valores. Por que investidores se interessariam em fazer aquisições privadas uma vez que as Bolsas de Valores existem justamente para dar transparência e liquidez aos títulos negociados? Duas razões levam os investidores a buscar os investimentos de PE/NC, conforme discutido a seguir.

A raison d'être do investimento em private equity está em sua estrutura institucional. Para que o mercado de valores mobiliários, em sua forma tradicional, possa funcionar é necessário que o processo de quebra de assimetria informacional ocorra de forma eficiente. Isso porque existe um conflito inerente de interesses entre os investidores e os gestores da empresa. É o chamado conflito de agência. Como os interesses de investidores e gestores numa empresa privada nunca estão completamente alinhados, são criados custosos mecanismos de controle e fornecimento de informações. Esses mecanismos, no entanto, não são infalíveis. Os exemplos recentes da Enron e Worldcom mostram como os administradores conseguiram esconder dos acionistas, principalmente dos minoritários, informaçōes relevantes sobre o desempenho de suas empresas.

Esse problema é agravado pelos vários conflitos de interesses existentes no mercado financeiro. A literatura em finanças tem dado atenção especial ao conflito entre principal e agente. em que o acionista ocupa o papel de principal e o adminis-

\footnotetext{
1 Caracterizaçâo comum na literatura de governança corporativa que segrega os mecanismos de financiamento em dois modelos bảsicos. O modelo de mercado de capitais é, normalmente, utilizado em paises de Direito Consuetudinário como Estados Unidos e Inglaterra e é baseado na oferta pública de titulos, especialmente açōes. Em paises de Direito Romano desenvolvidos, notadamente o caso da Alemanha e França, o financiamento das empresas se dá por intermédio do chamado insider model. Nesse modelo. os financiadores possuem informaçōes privilegiadas sobre as empresas investidas e não demandam informaçōes públicas. Normalmente, existem grandes concentrações acionárias e os financiadores. mais notadamente os Bancos, possuem até mesmo assentos nos boards das empresas.
} 
trador o de agente. No mundo real, no entanto, outros conflitos, igualmente importantes, estão acontecendo sem que se dê a devida atenção. O que se pode dizer, por exemplo, do conflito entre investidores minoritários e Bancos de Investimentos que são pressionados, muitas vezes, para dar recomendaçōes de investimento viesadas? E o conflito existente entre auditores e acionistas? Os auditores que deveriam primar integralmente por fornecer informaçōes sem viés aos acionistas, muitas vezes encontram-se dentro de sérios conflitos de interesse advindos de outras atividades com partes relacionadas. Assim, pode-se perceber que o mercado de valores mobiliários não funciona de forma completamente eficiente na alocação de recursos para investimentos e que esses conflitos podem ocasionar crises até mesmo sistêmicas na confiança e credibilidade do funcionamento do mercado.

Os veículos de investimentos (fundos de PENC) são estruturados de forma que os interesses dos empreendedores, dos gestores desses fundos e dos investidores de capital, cotistas dos fundos, sejam alinhados de modo contratualmente definido entre gestores, investidores e empreendedores. Nos EUA, a estrutura organizacional que confere esse tipo de benefício aos investimentos de PE/NC é a limited partnership. A relaçāo entre os investidores (limited partners) e os gestores de recursos (general partners) é feita em bases contratuais que procuram garantir o alinhamento de interesses. O objetivo central é estabelecer um contrato dentro do qual os interesses dos investidores estejam alinhados com os interesses dos gestores mitigando os incentivos para que os gestores, ou vice-versa, venham a se beneficiar sem que os investidores tenham a respectiva contraparte.

O modelo de remuneração e incentivos aos gestores, no Brasil, é estabelecido pelas Instruções CVM 391/03 e 209/94 que têm natureza eminentemente contratual entre as partes e dispõe sobre a participação dos gestores no processo decisório de companhias investidas abertas ou de capital fechado, sem limite de faturamento (CVM 391/03) estabelece diferenciação entre classes de cotas, estatui sobre o funcionamento de comitês de investimento, comitês técnicos e conselhos consultivos.

O regulamento do fundo, de natureza totalmente contratual, deverá dispor, também, sobre questōes de conflitos de interesses entre investidores e gestores, tais como decisões para a realização de investimentos e desinvestimentos, acesso de investidores a informaçōes sobre empresas da carteira do fundo, método para a determinação do valor de cotas e contabilização dos ativos e o tratamento de despesas relacionadas à gestão e operação dos fundos. São, igualmente, mandatórios o registro automático dos FIPs e FIEEs na Comissão de Valores Mobiliários - CVM, sua submissão bem como de sua ação fiscalizadora.

A estrutura típica dos fundos de PENC, que já tenham investimentos realizados (usualmente ao fim de 4 ou 5 anos após o lançamento), está indicada na Figura $1 \mathbf{0}$

O investimento em PENC permite que o investidor institucional de longo prazo (EFPC. Companhias de Seguros, Fundos Mútuos Especiais etc) possa construir uma carteira de ativos com características de risco e retorno distintas da carteira de açōes de mercado e da carteira de renda variável - outros ativos. Os custos para a quebra de assimetria informacional e resolução dos conflitos de agência são relativamente altos. As empresas participantes do mercado bursátil são, normalmente, de porte mais elevado. Essas empresas já possuem um histórico de operação que garante uma base mais sólida para a avaliação de seu desempenho passado e de sua governança societária.

Os Fundos de PE/NC (FIPs) permitem que os investidores tenham acesso a empresas em seus estágios iniciais de desenvolvimento, que precedem a abertura de capital e bem como que eles partilhem de retornos esperados potencialmente maiores, sujeitos, evidentemente, a mais baixos índices de liquidez.

Sem o apoio dos gestores de PENC, os empreendedores deveriam conduzir, de forma isolada, suas empresas até o momento no qual a abertura de capital ou o uso de dívida junto ao público pudesse ser realizado. Os empreendedores ficam. então, com toda a rentabilidade e risco auferido nesse processo. O PE/NC permite que parcerias possam ser realizadas

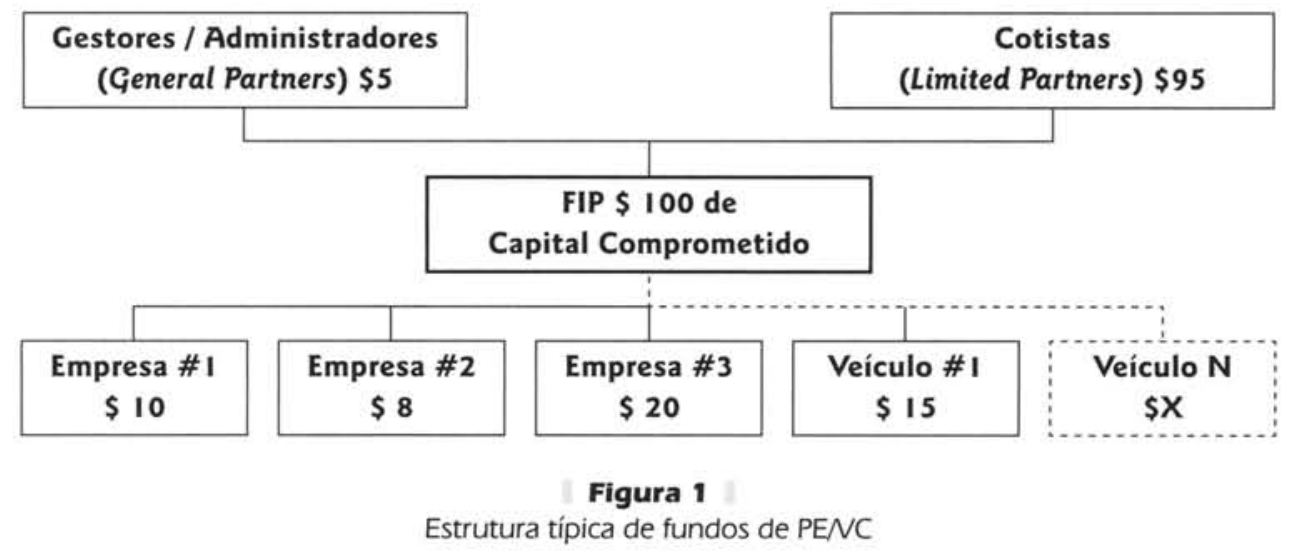


entre empreendedores e investidores nos estágios iniciais do processo de concepção e desenvolvimento e consolidação do negócio. Assim, os investidores institucionais em fundos de VC/PE podem ter acesso a empresas que dentro do modelo tradicional de acesso ao mercado aberto de valores mobiliários não estariam disponíveis.

Do ponto de vista da Teoria de Finanças, a existência de oportunidades de investimento em PE/NC permite que o mercado se torne mais completo, ou seja, os investidores podem associar fluxos futuros de caixa a estados da natureza que não estariam disponíveis inicialmente. De forma simples, o mercado financeiro tradicional não oferece investimentos com o perfil de risco e retorno que o PE/NC possui. Dessa forma, na pior das hipóteses, a existência dos Fundos de PE/NC contribui para que os investidores tenham uma riqueza maior de opçōes para alocar seus fluxos futuros de caixa.

Essa complementação de mercado trazida pelos fundos private equity faz com que a fronteira eficiente de ativos de risco possa ser alterada, em razāo da baixa correlação entre os ativos transacionados em mercado (public equity) com os de empresas das Carteiras de PE/NC.

O Gráfico 10 ilustra essa mudança na fronteira em que é possível ressaltar a melhoria na relaçāo custo/benefício trazida pela adoção desse ativo diferenciado dentro da carteira de investimentos de mercado. O Gráfico 1 foi construído a partir dos retornos esperados, desvios-padrão e correlação entre os ativos de private equity, ações e debêntures negociadas em mercado público de valores, conforme (SWENSEN. 2000).

Observando o Gráfico 1, percebe-se que, consistentemente com as observações empíricas, o ativo PE/NC tem retorno esperado igual ou superior à carteira tangente $\mathrm{P}^{*}$ e guarda correlação positiva e inferior à unidade com os retornos de $\mathrm{P}^{*}$. É possível construir uma política de alocação ao longo da CAL, (Capital Allocation Line), com a carteira P*', (que inclui VC/PE) que conduz a uma melhor relação risco/retorno na economia e, em particular, nas Carteiras das EFPCs, aliás, hoje, altamente concentradas em títulos federais.

A seção seguinte expande essa questão com foco específico nas entidades de Previdência Complementar. No entanto, a análise realizada pode ser, facilmente, estendida para outros investidores institucionais, tais como Companhias de Seguro e pessoas físicas qualificadas, respeitados os requisitos regulatórios.

A visão tradicional, nas pesquisas nesse setor, tem sido de que os investimentos em PE/NC dependem, fundamentalmente, do estado geral da economia, especialmente do comportamento de agregados macroeconômicos como PIB e taxas de juros. No entanto, pesquisas recentes (PELLÓN, 2001) demonstraram que a qualidade da gestão dos Fundos possui impacto significativo na criação de valor para os investidores e por conseqüência na capacidade dos gestores de levantar recursos junto aos investidores institucionais.

Os resultados, também, demonstram que os investidores institucionais são capazes de discriminar e selecionar Fundos pelas características de performance de seus gestores e, assim, orientar o fluxo de recursos. Essas conclusões são consistentes com as da literatura em Finanças para Initial Public Offerings (IPOs), como a de (GOMES, 2000) que empreendedores de alta reputação, comprometidos com alto nível de governança mesmo inexistindo mecanismos formais de controle. conseguem ter a qualidade de sua gestão incorporada ao valor de suas ações.

Adicionalmente. Pellón (2002) demonstra que a capacidade de levantar recursos por parte de Fundos de PE/NC depende, diretamente, dos sucessos passados dos seus gestores, nas operações de exit e do estado do mercado para empresas

$E(r)$

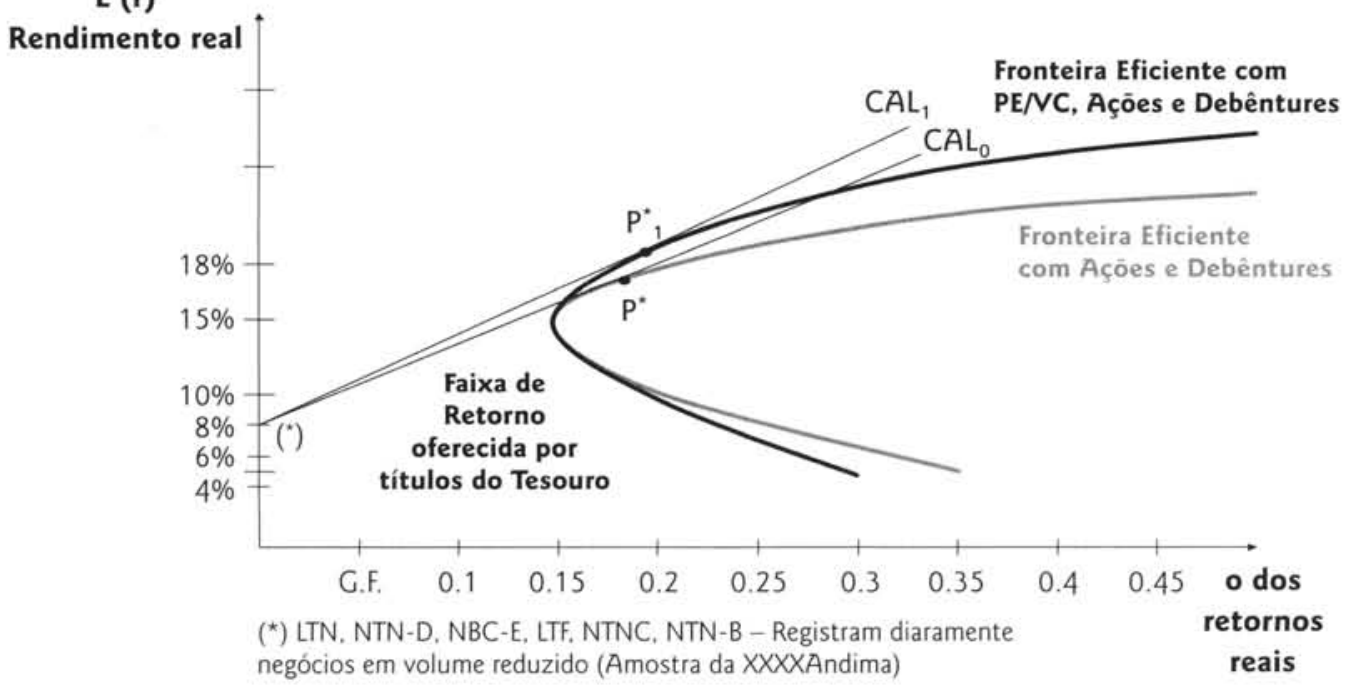

Gráfico 1

Alteração da Fronteira Eficiente de Mercado trazida pela adição de Fundos de PENC no portfolio 
em processo de crescimento. Esses fatores explicam de forma estatisticamente significante o fluxo de recursos para os investimentos de private equity na Europa.

O estágio inicial do $1^{2}$ ciclo não tem saída, mas há muitas empresas de sucesso nas carteiras. Uma ilustração dessa observação empírica está contida nos anexos em que são apresentadas algumas empresas da carteira de alguns Fundos de PENC no Brasil, que há pouco mais de sete anos inexistiam na economia, nem no conjunto de oportunidades de investimento das EFPCS.

É fundamental mencionar que o ambiente macroeconômico influencia diretamente na atratividade dos investimentos em PE/NC. O atual ambiente brasileiro, claramente, desencoraja os investimentos financeiros em ativos alternativos com características de equity (seja private, seja public). A elevada taxa de juros praticada pelo Governo Federal não incentiva investimentos em ativos de risco. Todas as observaçōes, aqui, realizadas devem ser consideradas tendo em vista o atual ambiente macroeconômico brasileiro, no qual ativos de renda fixa emitidos pelo Governo Federal dominam. estocasticamente, o índice representativo das ações negociadas em Bolsa.

Outro aspecto importante refere-se ao ambiente regulatório. A falta de portabilidade na maior parte das instituições de previdência fechada reduz a competição no setor, à medida que as instituiçōes não têm incentivos para se diferenciar pela qualidade da gestão. A evolução do ambiente regulatório microeconômico e macroeconômico, no Brasil, terá impactos significativos na decisão dos investidores institucionais de alocar recursos em ativos alternativos. A maior parte dos investidores institucionais brasileiros adota uma postura bastante passiva na gestão de seus investimentos porque as taxas de juros praticadas pelo governo têm sido suficientes para a cobertura da meta atuarial. À medida que se caminha para a estabilidade macroeconômica com a esperada reduçāo da taxa real de juros, aos gestores de investimentos das entidades de previdência complementar será necessária a introdução de melhorias técnicas para garantir a maximização do retorno das contribuições dos participantes dessas entidades para com quem os gestores têm um dever fiduciário. Nesse contexto, os investimentos em ativos alternativos como PENC ganharão maior relevância nas decisões de investimento das EFPCs.

\subsection{Alocação de Ativos da Carteira de Investimentos das Entidades Fechadas de Previdência Privada em PENC e Mezaninos}

As Entidades Fechadas de Previdência Privada (EFPP) e Companhias Seguradoras são investidores institucionais extremamente importantes para o funcionamento do mercado financeiro. Como possuem obrigaçōes com longo prazo de exigibilidade, essas instituiçōes podem investir em ativos com maturidade mais longa. Os Bancos Comerciais e de Investimento. tradicionalmente, não possuem essa mesma flexibilidade. Esse aspecto, acrescido do elevado montante envolvido, faz com que esses investidores institucionais tenham papel relevante no desenvolvimento do mercado financeiro, sendo agentes relevantes do financiamento de novas oportunidades de negócio.

A natureza dos compromissos assumidos por essas entidades (benefícios de aposentadoria, pecúlios, pensões, seguros etc.) fazem com que essas instituições busquem uma otimização conservadora dos seus investimentos. Limites claros de risco precisam ser estabelecidos e modelos de Asset Liability Management (ALM) são amplamente utilizados no setor. Em razăo dessas características, esses investidores possuem interesse especial na diversificação de suas carteiras. Pouco interessados em regras técnicas de trading, os investidores institucionais, normalmente, praticam estratégias de investimentos passivas no que se refere à renda variável.

Essa estratégia de investimentos é plenamente corroborada pela literatura em Finanças. $\mathrm{O}$ aumento do número de ativos com baixa correlaçāo de retornos entre si na carteira reduz o risco do portfolio, otimizando a relaçāo entre risco e retorno para a instituição detentora dos títulos. A simplicidade dessa estratégia, no entanto, é só teórica. Em um país como o Brasil diversos problemas impedem que um investidor institucional tenha uma carteira realmente diversificada.

Inicialmente, os ativos negociados em Bolsa de Valores não são representativos da larga diversificação de atividades encontrada no setor real da economia brasileira. Poucas são as empresas que realmente procuram as Bolsas de Valores para seu financiamento, de forma que a representatividade da carteira de ações negociadas na Bolsa em relação ao setor real da economia fica prejudicada. Em segundo lugar, a liquidez dos títulos não permite que os investidores assumam posições de forma homogênea nos títulos negociados em Bolsa. Os investidores acabam tendo que condicionar suas decisões de investimento a fatores exógenos que influenciam a liquidez dos títulos negociados. Essa impossibilidade de diversificaçāo ampla acaba por impedir que todo o risco diversificável seja realmente diversificado. Os investidores institucionais terminam por carregar em suas carteiras risco idiossincrático em adição ao risco não diversificável descrito pela teoria. O gráfico $2 \bigcirc$ ilustra essa situação.

A linha escura demonstra um portfolio ideal composto por uma amostra significativa das atividades econômicas reais. Esse portfolio permitiria que o investidor carregasse, no limite, somente o risco de "mercado" nāo diversificável. Esse investidor estaria plenamente diversificado. A sua carteira somente possuiria o risco sistemático em seu mercado de atuação. Infelizmente, essa situação teórica não é factível no Brasil.

A outra linha demonstra com mais realismo o que ocorre em um mercado emergente. As empresas não conseguem, pelas razōes expostas anteriormente, diversificar o seu portfolio de maneira eficiente. Com base nessa exposiçăo, pode-se perceber que iniciativas no sentido de melhorar a diversificação das carteiras dos investidores institucionais são realmente importantes. 


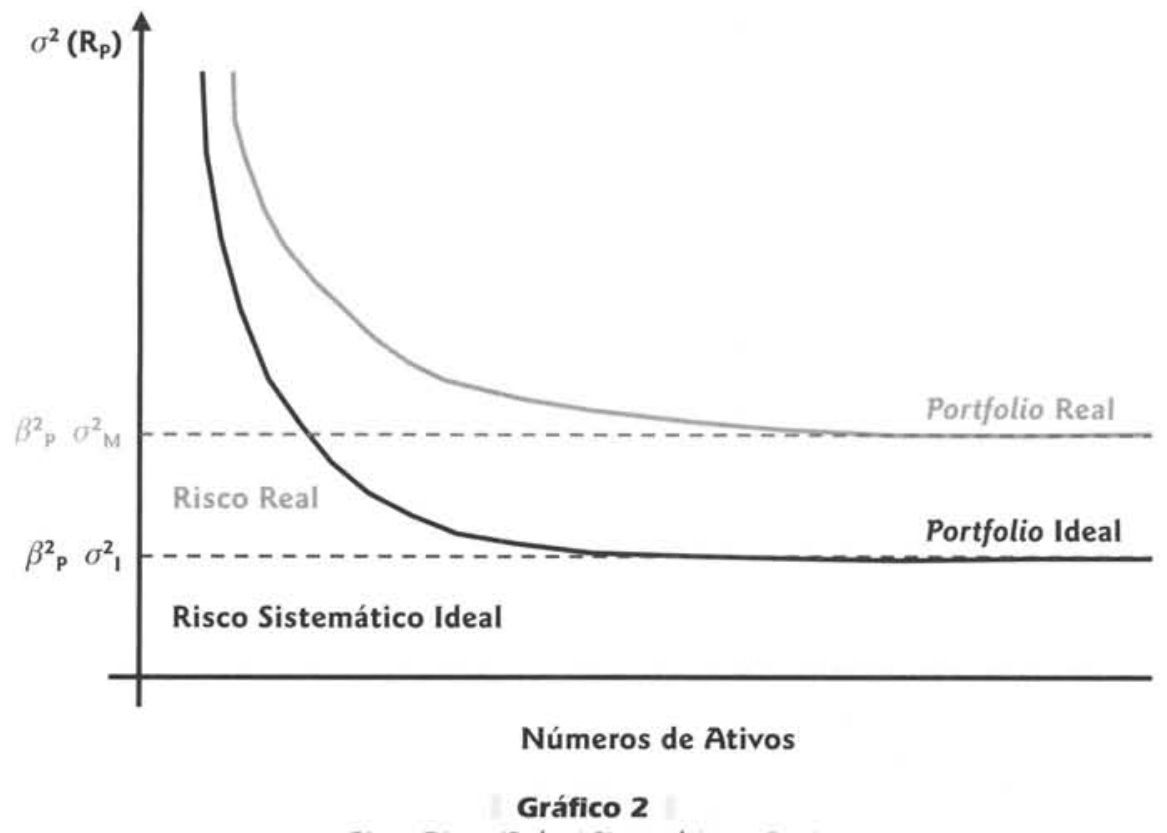

Risco Diversificável Sistemático e Real

Qual o papel dos Fundos de PE/VC nesse cenário? A análise é simples e apresentada a seguir. Pode-se afirmar, com grande segurança, que os setores para os quais são direcionados os investimentos de PE/VC são bastante distintos daqueles normalmente negociados em Bolsas de Valores com os quais exibem baixa correlação.

Conforme estudo da Thomson Venture Economics, no primeiro semestre de 2002, os investimentos em PE/VC nos setores de medicina/saúde/biotecnologia e tecnologia da informação corresponderam a $70 \%$ do total investido. Esses setores não possuem a mesma representatividade no Ibovespa. Há indícios bem claros de que o investimento dos Fundos de PE/NC no Brasil estejam concentrados em empreendimentos que são fracamente correlacionados àqueles da carteira do IBX. As tabelas A.1 e A.2 anexas apresentam algumas dessas correlaçōes para o mercado norte-americano. É razoável considerar que os resultados para o Brasil devam apresentar números ainda menores. Isso se deve às características do mercado acionário local que deve guardar correlação ainda menor com os ativos típicos dos Fundos de private equity brasileiros.

Outro aspecto que precisa ser levado em conta é que o investimento em PENC, no Brasil, pode ser uma alternativa viável para a diversificaçāo internacional. Note-se a correlação de 0.30 entre ações norte-americanas e aquelas de países emergentes e de 0.10 entre private equity norte-americano e de países emergentes, e 0.30 entre ações em mercados desenvolvidos e private equity.

A diversificação internacional, ainda, não é viável para os investidores institucionais brasileiros em virtude de limitações regulatórias. No entanto, como pode ser visto pela composição da carteira de investimento em PE/NC no Brasil, os setores investidos assemelham-se mais aos ativos negociados em Bolsas de Valores estrangeiras (especialmente no caso norte-americano com a NASDAQ) do que aos setores negociados nas Bolsas brasileiras. Assim, o investimento em PE/NC melhora a composição do portfolio dos investidores institucionais brasileiros aproximando-os de seus correspondentes internacionais, reduzindo-se o risco diversificável carregado em suas carteiras que onera os participantes.

Um aspecto adicional que merece destaque é que os investimentos em PENC apresentam um prêmio sobre os investimentos tradicionais em mercados de capitais. O gráfico $3 \boldsymbol{0}$. apresenta essa rentabilidade para os investimentos nos Estados Unidos e Europa.

Com base no exposto acima, pode-se considerar que os investimentos em private equity constituem modalidades de investimento que podem agregar valor significativo para a gestão de carteiras de investidores institucionais como entidades fechadas de Previdência Privada e Seguradoras. Ou seja, além dos aspectos relevantes demonstrados do ponto de vista econômico, os investimentos em private equity e venture capital constituem-se em alternativas importantes do ponto de vista de melhora do perfil risco e retorno das carteiras de investimentos das quais participem.

Pesquisas recentes nos EUA (LJUNGQVIST. 2003) apresentam resultados conclusivos e de grande interesse sobre o investimento em Fundos de PENC. As categorias estudadas foram Fundos de buy-out e venture capital.

O estudo coletou uma amostra muito representativa de Fundos constituídos entre 1981 e 2001. Dos Fundos maduros. constituídos entre 1981 e 1993, 74\% eram private equity (buy-out) e $26 \%$ eram venture capital. Os resultados sobre rentabilidade e risco foram computados por 20 anos até o final de 2002. 


\section{Private Equity na Europa e Estados Unidos \\ Taxas internas de retorno: Acumulado desde a data de criação dos fundos até 2003. \\ Data-base de criação dos fundos: 31.12 .1979}

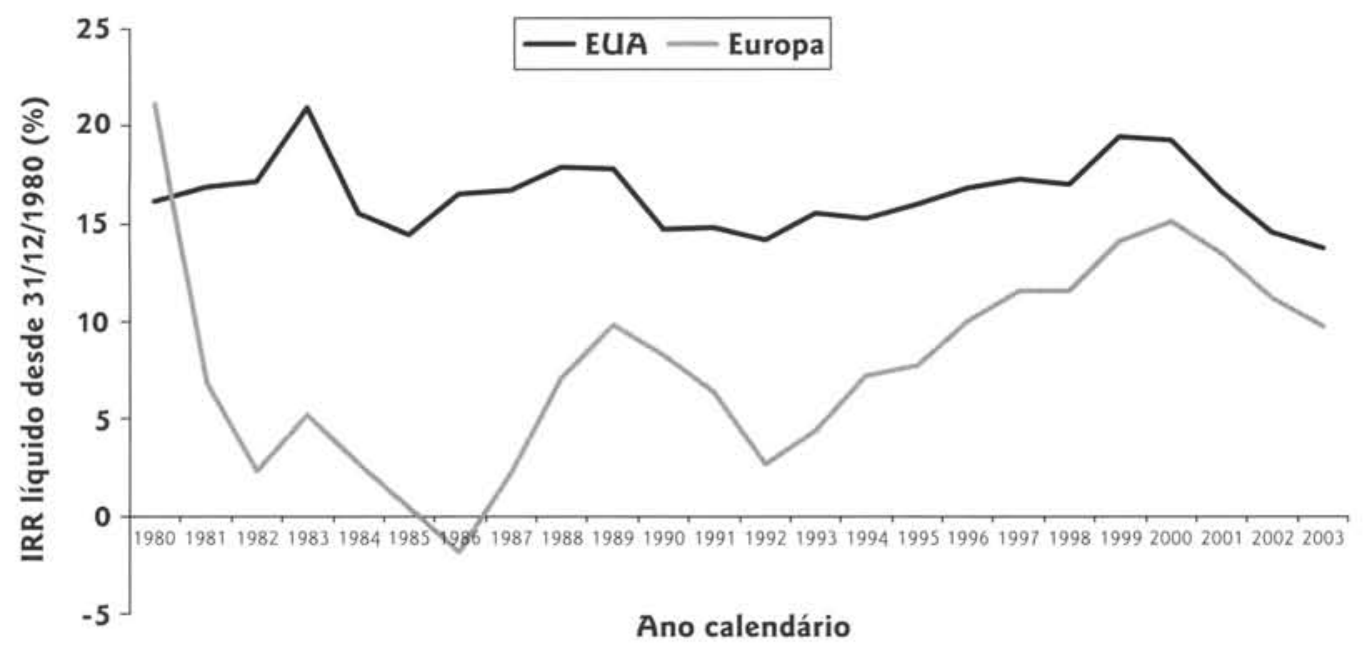

Fonte: Thomson Financial's VentureXpert database

\section{Gráfico 3}

Retorno Comparativo dos Investimentos em Private Equity

Os betas das empresas investidas são, em média, superiores a 1. Considerando os fluxos de caixa das empresas investidas descontados ao seu custo de capital ajustado ao risco, obtém-se um índice de criaçăo de valor nas empresas de 24\% (profitablility index). Os Fundos maduros ofereceram taxa de retorno de $19.8 \%$ ao ano livre de despesas e taxas administrativas nas décadas examinadas. Apenas para efeito comparativo, o retorno do índice S\&P 500 no mesmo período foi de $14.7 \%$ ao ano.

É discutível se o elevado retorno excedente pago aos investidores de Fundos de PE/NC. 5.37\% a.a., resulta de compensação pela baixíssima liquidez - longa maturidade desses fundos. De fato há que considerar um efeito de clientela: os investidores institucionais (Fundos de Pensão, Companhias Seguradoras etc.) já desenham suas estratégias de investir em PE/VC conhecendo a duração de seus passivos e podem casar prazos com seus investimentos em PE/NC.

O cronograma de desembolso do capital comprometido nas empresas investidas também é longo e depende de fatores tais como: competição entre gestores por oportunidades e volume do fluxo de recursos do capital comprometido.

Documenta-se, também, que há um prazo médio de 3 e 6 anos para que 57\% e 91\%, respectivamente, do capital comprometido seja efetivamente investido. Isso é importante porque não necessariamente a criação de Fundos, com o conseqüente comprometimento de capital de investidores, leva a uma onda (ou bolha) de investimentos, ao menos na indústria de PE/NC madura.

Outro resultado importantíssimo diz respeito à realização monetária (caixa) das altas taxas de retorno obtidas pelos Fundos: a taxa interna de retorno das empresas investidas não se torna positiva até o oitavo ano de vida do Fundo. quando são realizadas as saídas de investimentos ou distribuição de retornos em base de caixa.

É importante esse resultado empírico para a nascente indústria de PENC no Brasil que tem não mais de 7 anos de existência. Não se pode ainda esperar track record de realização monetária dos fundos da nossa indústria. Há que examinar as empresas das carteiras dos Fundos, a qualidade dos gestores e de seus métodos de gestăo.

Finalmente, outra verificação empírica é que os Fundos considerados individualmente não são bem diversificados: em média $40 \%$ do capital investido é concentrado em um tipo de indústria, reflexo do grau de maturidade e especialização da indústria norte-americana de Fundos de PENC. No Brasil, a situação pode ser diferente mas não há resultados empíricos confiáveis sobre o tema. A maneira de o investidor institucional diversificar no Brasil é, após selecionar os gestores, formar uma carteira diversificada de investimentos em fundos de PE/NC.

Weidig (2004) estuda diversas alternativas de investimentos, considerando: (a) investimento direto de venture capital numa empresa; (b) investimento num Fundo de venture capital ou buy-out e (c) investimento numa carteira de fundos de PENC.

O investimento direto em uma empresa possui alto risco de perda total, ordem de $30 \%$, sua distribuiçāo sendo bem assimétrica à esquerda, e a probabilidade de alguma perda - retornos inferiores ao capital investido - é de $42 \%$. A probabilidade de ganho, também. é elevada, quase $25 \%$.

Entretanto, a diversificação tem profundos efeitos nos investimentos de PE/NC. Examinando resultados dos Fundos maduros (mais de 5 anos) nos EUA e Europa entre 1983 e 1998 com 10 a 20 empresas investidas, chega-se a uma proba- 


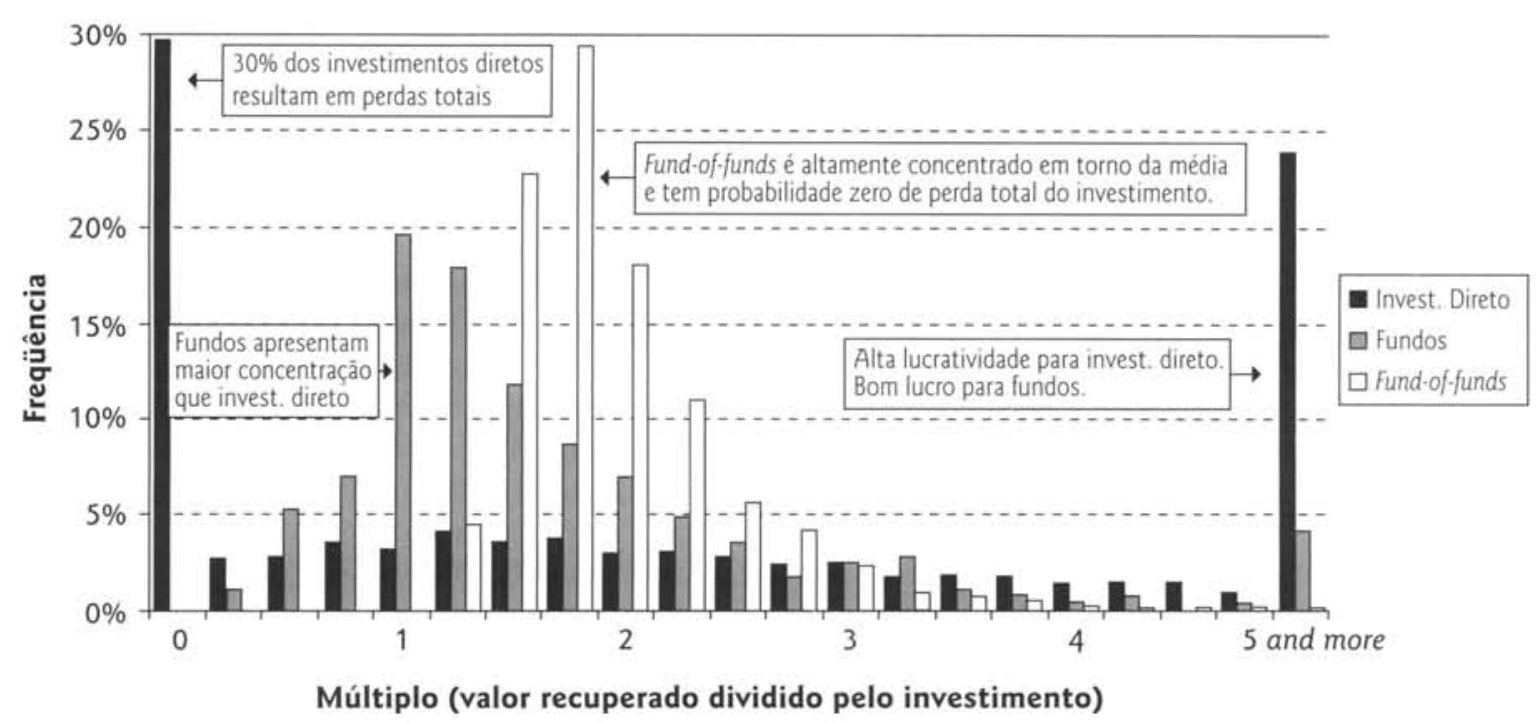

Copyright: Weidig and Mathonet 2003

Sources: VentureXperts. Cochrane

Corporação do perfil de risco de veículos de investimento em Venture Capital: Distribuição Múltipla. (Dados apresentam cerca de 5.000 investimentos diretos (somente dados dos EUA - năo havia dados europeus), cerca de 500 fundos europeus e 50.000 fund-of-funds europeus simulados.)

\section{Gráfico 4}

O Perfil de Risco dos Veículos de Venture Capital

bilidade nula de perda total, embora a probabilidade de não se obter a devolução de até $100 \%$ do capital investido fique em torno de $30 \%$.

O investimento numa carteira de Fundos de PENC ou fund-of-funds é o mais recomendado para investidores que não possuam competência necessária para administrar participaçōes em Fundos de PENC como "limited partners" e que sejam totalmente avessos à perda de capital. Nessa modalidade de investimento. considerando uma Carteira de Fundos constituída de vinte Fundos de PENC. a probabilidade de nāo recuperar o capital investido (qualquer perda) é muito diminuta. Ademais, a probabilidade acumulada da razão entre os recursos totais em dinheiro devolvidos aos investidores dividido pelo capital investido ficar no intervalo de 1,25 e 2,25 é de aproximadamente $88 \%$. (Gráfico 4 O).

\subsection{Quanto Investir em Private Equity e Venture Capita?}

Conforme visto acima, parecem nāo faltar argumentos que sugiram que os investimentos em PE/NC podem agregar enormes benefícios para os Fundos de Pensão e demais investidores institucionais.

A CalPERS ${ }^{2}$ (California Public Employees' Retirement System) criou, inclusive, um programa especial para se especializar na gestāo dessa classe de ativos o (Alternative Investment Management - AIM). Os objetivos estratégicos do investimento em private equity sāo: (i) incrementar, no longo prazo, o retorno ajustado ao risco da CalPERS; (ii) aumentar a reputação da CalPERS como um gestor de primeira linha de ativos alternativos e se tornar o investidor de referência na comunidade de private equity: (iii) travar risco contra passivos de longo prazo e (iv) prover diversificação ao programa geral de investimento da CaIPERS.

Dessa forma, pode-se ver como o investimento em private equity representa uma alternativa importante de investimento nos mercados de investimentos maduros.

No entanto, parece faltar um conjunto de diretrizes objetivas visando determinar quanto deve ser investido em ativos alternativos pelos investidores institucionais. Essa pergunta insere-se diretamente dentro da modelagem de Asset Liability Management - ALM das entidades de previdência, ou seja, para esses investidores institucionais, os investimentos de PE/NC devem ser entendidos dentro do contexto geral de otimização intertemporal visando oferecer o melhor perfil risco retorno e a cobertura adequada das obrigações atuariais.

A modelagem tradicional (single period mean-variance portfolio theory) năo pode ser aplicada diretamente aos investimentos em PE/NC por três razôes básicas. Em primeiro lugar, esses investimentos não possuem liquidez em mercados

2 Um dos maiores investidores institucionais do mercado de açôes internacional com um portfolio de US\$ 179 bilhōes, sendo que quase US\$ 21 bilhỏes em private equity. Esse valor torna a CaIPERS a maior investidora de private equity do mundo. Dados referentes ao mês de Junho de 2004. 
organizados o que possibilitaria a definição do vetor de retornos e da matriz de correlaçōes necessárias para a geração da fronteira eficiente no horizonte de um período. Não existe perspectiva de solução/alteração desse problema uma vez que a característica de investimento em empresas fechadas é um dos grandes atrativos do modelo de PE/NC.

Em segundo lugar, a otimização para as entidades de previdência precisa ser enxergada em um contexto estocástico de longo prazo, ou seja, a otimização de um período fornecida pela modelagem tradicional não se adapta ao problema de ALM das entidades de previdência privada e demais investidores institucionais.

Finalmente, uma entidade de previdência possui passivos representados por seus compromissos atuariais. Esses passivos possuem características próprias de comportamento no longo prazo e características financeiras que precisam ser consideradas na solução de ALM. Por exemplo, existem correlaçōes entre as variáveis que impactam no valor dos benefícios a serem pagos e no valor dos ativos. A taxa de juros fornece um bom exemplo desse fenômeno, ou seja, é necessário que se considerem os impactos das flutuaçōes nas variáveis econômicas no valor dos ativos e nos passivos. Dessa forma, pode-se ver que os investimentos em PENC não podem ser avaliados dentro da estrutura tradicional de otimização de um período em Finanças.

Alternativamente, sugere-se o modelo de otimização apresentado pelo Prof. Mulvey da Universidade de Princeton (MULVEY, 2000). A estrutura básica do modelo é apresentada na Figura 20.

Pode-se ver que o processo é composto de três etapas interdependentes: (i) geração de cenários; (ii) simulação das decisōes de investimento e (iii) otimização das decisōes realizadas tendo em vista o impacto na Carteira. O processo de geração de cenários é fundamental para a simulação, uma vez que as variáveis aleatórias precisam ser projetadas no longo prazo. Esse sistema de equações estocásticas é conhecido como gerador de cenários.

Vários simuladores vêm sendo utilizados por atuários, planejadores financeiros e outros profissionais da área. No Reino Unido, o modelo mais usado talvez seja o de Wilkie (1987) mas Mulvey (1989) também desenvolveu um modelo para a Pacific Mutual. Esses cenários possuem uma estrutura de cascata não linear de forma que métodos tradicionais, como maximum likelihood, não funcionam bem. A geração de cenários fornece a base para todo o processo subseqüente. $\mathrm{O}$ teste do bom senso deve ser aplicado na estrutura de geração dos cenários para verificar se os paths gerados são razoáveis. Apesar dos geradores de cenários já serem usados há muito tempo em outras áreas (como previsão de eventos climáticos) três aspectos merecem atenção especial: (i) realismo das equações do modelo; (ii) calibração dos parâmetros e (iii) procedimentos de amostragem. O processo de backtesting (teste das previsōes do modelo em relação a dados passados) é fundamental para aferir o grau de precisão do modelo e deve ser feito em base contínua.

O objetivo de um simulador de decisōes é replicar o comportamento do investidor ao longo do tempo em suas decisōes mais importantes. Devem ser definidos pontos críticos relacionados às principais decisões tomadas uma vez que não se pode simular todas as decisões tomadas. O realismo da simulação da decisão tomada é fundamental uma vez que todos os resultados seguintes serão baseados nessas decisões. No caso de uma entidade de previdência devem ser simulados os processos de decisão ligados à alocação de ativos e ao pagamento de benefícios. No processo de otimização não será encontrado um único ponto ótimo e definitivo. O processo de controle estocástico é uma das técnicas mais simples que podem ser usadas nesse aspecto. A programação estocástica de vários estágios é também utilizada, principalmente quando o controle estocástico nāo é bem adaptado (por exemplo, quando se trata de regulamentaçōes e outros eventos dessa natureza). Essa abordagem é baseada em árvores de decisão para os principais eventos considerados. Para simplificar o processo, podem ser definidas políticas ou regras de decisão que possibilitem reduzir características do problema para variáveis mais facilmente tratáveis.

Dessa forma, pode-se considerar que a abordagem da otimização intertemporal estocástica é a mais adequada para tratar com investimento em PE/VC devido às características desses ativos.

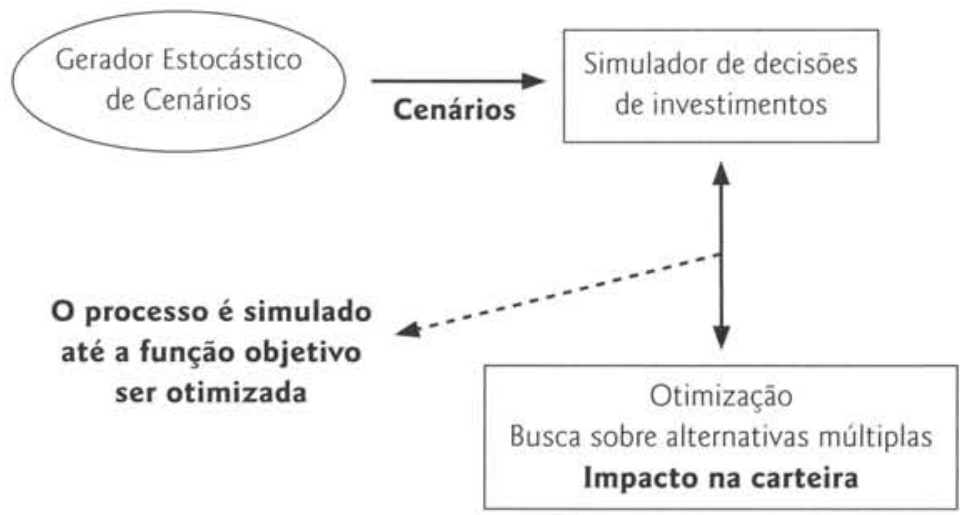

Figura 2

Elementos da Otimizaçăo em Períodos Múltiplos 


\section{VALORAC̣ÃO (CONTABILIZAC̣ÃO) DAS COTAS DOS FUNDOS}

Durante a pesquisa realizada, pode-se observar que não existem pronunciamentos definitivos sobre a contabilizaçāo das cotas de Fundos de PE/NC que não possuem cotação corrente de mercado. O tema é controverso e altamente debatido pelas entidades representativas de gestores e investidores no exterior e no Brasil mais recentemente. Pode-se concluir que os principais órgãos normatizadores da Contabilidade internacional (especialmente o FASB, ASB e o IASB) ainda não se pronunciaram diretamente sobre o assunto. No entanto, pode-se observar, também, que esses referidos órgãos normatizadores já haviam emitido opinião objetiva no que se refere à avaliação de participações acionárias de sociedades coligadas e controladas no contexto de fusōes e aquisições. Apesar de tratar de um contexto operacional diferente, em suma, tem-se um problema contábil de natureza similar, ou seja, a avaliação de investimentos para os quais o custo histórico não possui relevância informacional e o valor de mercado (ou fair value) não esteja prontamente disponível.

Recentemente, a International Finance Corporation (IFC) em um projeto conjunto com o Swiss State Secretariat for Economic Affairs, emitiu os primeiros resultados de um estudo que visa harmonizar o tratamento contábil das operaçōes de private equity. O conceito central do estudo é a figura do fair value como base para as avaliaçōes. No entanto, o texto dá atenção especial ao conservadorismo visando evitar superavaliaçōes. Esse aspecto é especialmente importante quando a remuneração dos administradores está baseada no valor de mercado dos ativos ou no valor dos investimentos. Mais especificamente, o quadro $1 \mathbf{O}$ apresenta as recomendaçōes para as principais categorias de ativos sendo avaliadas em mercados emergentes.

Algumas observações são importantes para aplicar esse tipo de avaliação. Inicialmente, a avaliação está sujeita ao alto grau de julgamento dos avaliadores, no caso da utilização de métodos de avaliação como DCF ou múltiplos operacionais (EBITDA, vendas, ativos etc.). Assim, a figura do impairment passa a ser extremamente importante. O impairment năo existe na contabilidade brasileira e refere-se à baixa de qualquer ativo que năo possua mais relevância econômica, ou seja, os ativos são definidos como elementos que possuem potencial de geraçăo de benefícios econômicos futuros para a empresa.

Quando esses benefícios nāo forem mais prováveis os ativos devem sofrer baixa (write-off). Esse processo, no entanto, deve ser objeto de avaliação independente. No caso da avaliaçāo de intangíveis, os auditores - com alto grau de independência - devem realizar o teste de impairment anualmente. Esse aspecto é importante no caso dos investimentos em PE/VC quando a avaliação dos ativos pode de alguma forma ligar-se às taxas de administração cobradas pelos gestores.

Torna-se fundamental que a determinação do fair value seja feita de forma apropriada e fundamentada na sólida avaliação de crescimento e oportunidades de negócios futuros. Dessa forma, por analogia, os principais pronunciamentos dos referidos órgãos podem constituir-se em alternativas de referência para a mensuração dos investimentos em private equity e cálculo das respectivas cotas dos fundos.

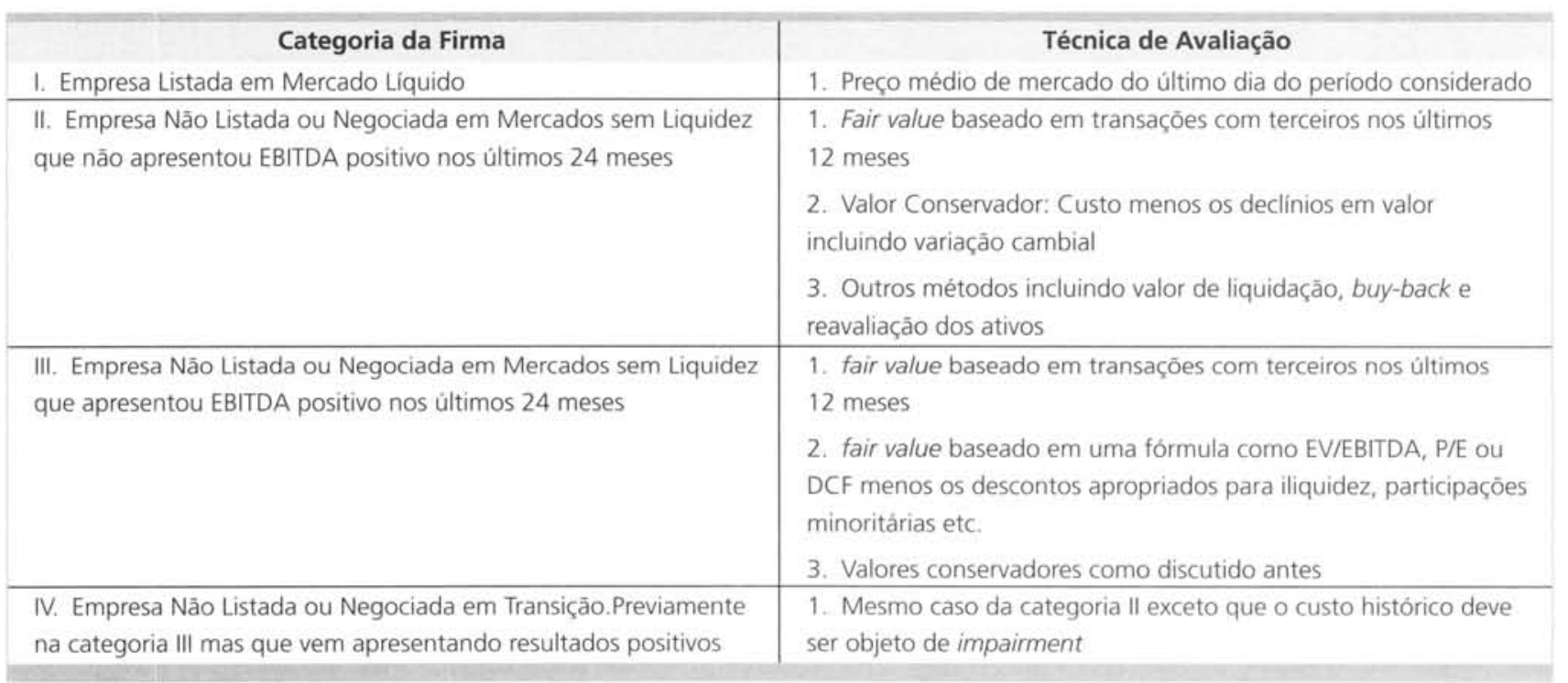


A) Accounting Standards Board - ASB

O FRS 7 define fair value como:

[...] as the amount at which an asset or liability could be exchanged in a transaction in an arm's length transaction between informed and willing parties, other than in a forced or liquidation sale. ${ }^{3}$

Essa definição, bastante conceitual, é detalhada pelo FRS dentro de algumas categorias selecionadas abaixo:

a) Ativos Não Monetários: O FRS 7 afirma que: (i) Ativos Fixos Tangiveis: o fair value de ativos fixos tangíveis deve ser baseado no valor de mercado se ativos similares forem negociados livremente no mercado com frequeência razoável. Na ausência dessa informação, recomenda-se a utilização do custo de reposição depreciado refletindo a utilização do bem pela empresa. O pronunciamento deixa claro que o fair value não pode superar o valor que seria obtido pelo ativo em sua negociação (recoverable amount). Em muitas situaçōes, o custo histórico corrigido por um índice adequado de inflação representa a melhor medida do fair value dentro dessa categoria; (ii) Intangíveis: ativos intangiveis, como patentes, devem ser reconhecidos pelo valor de mercado que é a melhor estimativa de goodwill. Não existe no pronunciamento uma indicaçāo clara de como esse valor deve ser mensurado; (iii) Investimentos: para a avaliação de investimentos também prevalece a utilização do preço de mercado sem que seja feita uma discussão mais detalhada de como esse valor deve ser atribuído no caso de empresas fechadas e outras situações nas quais não existam valores de mercado claramente especificados.

b) Provisōes: não devem ser consideradas aquelas que se referem às provisões para re-estruturações que não serão continuadas pela adquirente, Dessa forma, destaca-se a importância da segregação dos eventos pertinentes à empresa adquirida que não mais serão realizados pela empresa ou fundo adquirente.

Pode-se observar que dentro do modelo Inglês o instituto do fair value predomina na avaliação das várias categorias de ativos. É relevante ressaltar a diferença do conceito inglês de fair value do conceito comum na legislação francesa de image fidelis. No conceito inglês o que importa é a relevância econômica da transação medida por sua capacidade de gerar fluxos futuros de caixa. Dentro do modelo francês, o image fidelis refere-se à representaçāo fidedigna em relaçāo ao exposto no texto legal, ou seja, imagem fiel em relaçâo à legislaçăo.

B) O Financial Accounting Standards Board - FASB

A base de mensuração dos ativos deverá ser o fair value no momento da aquisição.

Dessa forma, pode-se perceber que a estrutura do FAS 141 é similar à do FRS 7 no que se refere ao entendimento da transação realizada e da mensuração dos ativos e passivos. Assim, ativos e passivos devem ser mensurados pelo fair value no momento da aquisição, ou seja, o FASB adota medida similar ao seu colega regulador inglês no que se refere à mensuração de ativos e passivos.

C) International Accounting Standards Board - IASB

O IASB, em seu pronunciamento 22 - Business Combinations, estabelece que os ativos e passivos envolvidos em fusōes e aquisiçōes devem ser mensurados pelo fair value. Dessa forma, o órgão normatizador internacional adota postura similar aos seus correspondentes ingleses e norte-americanos.

D) Contribuição para o Debate sobre a Valoração de Cotas de Investimentos na Indústria de Private Equity e Venture Capital Com base no exposto acima. pode-se considerar que o fair value seja o método adequado para a valoração dos investimentos de private equity. A periodicidade de tais avaliações deve ser, pelo menos, anual. A avaliação deverá ser realizada por avaliador independente que não possua vested interests na performance do fundo.

Diversas metodologias podem ser adotadas para a estimação do fair value de investimentos. Normalmente, essas estimativas estão relacionadas a instrumentos financeiros que não possuem negociação em mercados organizados. No entanto, analogias podem ser construídas para a indústria de private equity. Lopes (2003) comenta sobre os modelos de estimação do fair value e mostra que esses devem, inicialmente, estar baseados em transaçōes similares.

Alternativamente, devem ser utilizados modelos de simulação e avaliação que podem estar fundamentados no fluxo de caixa futuro descontado da operação ou em múltiplos relativos a operações similares realizadas em outras indústrias para as quais exista a disponibilidade de valores de mercado. De uma forma sucinta, esse processo de estimação deve levar sempre em conta a essência econômica da transaçāo e o conceito de arms lenght, ou seja, as operaçōes devem ser analisadas como se fossem realizadas em situações de mercado organizado preservando o true and fair view da operação. A Legislação Societária e Fiscal Brasileira acolheu o conceito de avaliação com base em "rentabilidade futura".

3 FRS 7 parágrafo 2. 
Nesse ponto, cabe uma observação sobre a estrutura jurídica dentro da qual a Contabilidade está inserida. Os modelos contábeis citados (FASB, ASB e IASB) privilegiam a figura do fair value sobre o custo histórico como métrica adequada para a avaliação de ativos de uma forma geral. Deve-se lembrar, no entanto. que as jurisdiçōes dentro das quais as referidas normas são aplicadas adotam o Direito Consuetudinário (Common Law) e não o Direito Civil (Civil Law) como é o caso brasileiro.

Como as pesquisas recentes sobre governança (LOPES. 2002) indicam, em países de Direito Consuetudinário, os acionistas e demais investidores gozam do chamado duty of loyalty em relação aos administradores e demais gestores de recursos. Reza esse princípio que, nas situaçōes que não estiverem claramente previstas nos contratos estabelecidos, os gestores devem agir sempre de acordo com os interesses dos acionistas (cotistas, limited partners). Além dessa prescrição, cabe lembrar que as Cortes, nesses países, não irão julgar os administradores de acordo com as normas definidas no contrato ad nascendum. Os juízes irão interpretar o conceito de duty of loyalty e garantirão o enforcement desse instituto independente dos termos explícitos contratuais. No direito anglo-saxão, esse conceito vale mais do que os termos explicitos em cada regulamento de Fundos de PE/NC. É uma forma de se operacionalizar contratos incompletos em ambientes demasiadamente complexos.

Assim, vale a pena ressaltar a importância de serem analisados os impactos jurídicos da avaliação dos ativos de private equity por seu fair value dentro do ambiente legal brasileiro e sua periodicidade. Pelo regulamento do FIP, essa norma pode ser estabelecida entre as partes. A experiência mostra que o Judiciário, no Brasil, tende a se ater aos termos estritos da legislação e ignorar o contexto econômico ou contratual dentro do qual elas foram criadas. ou seja, a aplicaçăo de conceitos como fair value e impairment dentro do ambiente brasileiro precisa ser feita tomando-se esses cuidados de natureza jurídica.

\section{SELEÇÃO DE GESTORES: O RELACIONAMENTO DO INVESTIDOR (LIMITED PARTNER) COM O GESTOR (GENERAL PARTNER) E A OUESTÃO DA GOVERNANÇA}

Em recente apresentação a Fundos de Pensão Brasileiros, Barger (2004) abordou a questão central do processo de seleção dos gestores em palestra intitulada: "How to be a Vigilant Fund Investor".

Seu tema de abertura foi emblemático:

"Sucesso em PE não é sorte, mas sim habilidade".

Revelou, também, um estudo da McKinsey na Europa que conclui:

Se o seu fundo está entre os $25 \%$ melhores fundos, existe uma chance de $45 \%$ que seu próximo fundo esteja novamente entre os $25 \%$ melhores e $73 \%$ de chance que esteja entre os $50 \%$ melhores. Um novo time de gestores tem uma chance de $16 \%$ de estar entre os $25 \%$ melhores. Assim, o sucesso em PE está relacionado a persistência.

A comparação entre as diferenças de habilidades dos gestores das principais categorias de ativos da Carteira de Investidores Institucionais revela-se no Gráfico 50.

Note-se que, enquanto a relação de um bom ou mau gestor pode significar uma diferença no retorno anual (entre 1980 e 1985) de 1.1\% e 2,3\% no caso de renda fixa e açōes, respectivamente, selecionar um mau gestor de PE/VC ao invés de um bom pode significar uma diferença de $15 \%$ a.a. nos EUA e $25 \%$ na Europa.

Essas conclusōes são corroboradas pelo mais recente artigo acadêmico sobre a performance de Fundos de venture capital e buy out individuais, no período 1970 a 2000. elaborado pelos professores Steven Kaplan e Antoinette Schoar (2004). utilizando 746 Fundos que foram levantados antes de 1997 e liquidados.

Utilizando metodologia (PME), em que se obtém a razão entre todos os recursos de capital colocados no Fundo e todas as distribuiçōes do Fundo, ambos remunerados à taxa de retorno do índice S\&P500, o retorno para os investidores do Fundo (limited partners) é avaliado líquido de taxa de administração, despesas e carried interest.

Considerando a amostra total, a taxa interna de retorno média, no período, foi de $18 \%$ a.a., tendo a amostra de venture capital superado em $22 \%$ o retorno de investimentos equivalentes no S\&P500, enquanto os Fundos de buy out tiveram performance $7 \%$ inferior.

A mais interessante evidência empírica foram as enormes diferenças de performance entre o quartil inferior (TIR de 4\%) e o quartil superior (TIR de 23\%) da amostra, o que confirma o resultado anterior.

Mais interessante, entretanto, é que, diferentemente da indústria de Fundos Mútuos, existe inequívoca evidência de persistência de performance: existe grande persistência de retorno entre fundos do mesmo general partner, mas os retornos se reduzem quando os general partners levantam fundos muito grandes. 
Período 1980-95 (E.U.A)

\begin{tabular}{|c|c|c|}
\hline Private Equity nos EUA (\%) & Ações (\%) & Renda Fixa (\%) \\
\hline 25\% Melhores IIIIIIIIIIIIIIIIIIII 21.9 & | [IIIIIIIIIIIIII 17.0 & 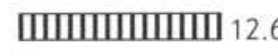 \\
\hline Mediana IIIIIIIIIIIIII 14.0 & ШIIIIIIIIIII 15.9 & IIIIIIIIIII 12.0 \\
\hline 25\% Piores [IIIIII 6.9 & ШIIIIIIII) 14.8 & 11.5 \\
\hline
\end{tabular}

Diferença entre os $25 \%$

melhores e os $25 \%$ piores

[IIIIIIIIIIIIIII] 15.0

IIII 2.3

[1.1

Periodo 1993-95 (Europa)

Diferença entre os $25 \%$

melhores e os $25 \%$ piores

\section{IIIIIIIIIIIIIIIIIIIIII 25.2}

Fonte: Apresentaçāo Teresa Barger, Rio, maio 2004. Apud McKinsey Company.

\section{Gráfico 5}

Performance dos Fundos nos EUA e Europa. Diferença entre gestores

Resultado natural e esperado é que "first time funds" desempenham pior que a média da indústria, em grande parte porque, numa indústria madura, depois de períodos de bom desempenho, um grande número de fundos entra na indústria e não têm o mesmo desempenho médio.

Está empiricamente demonstrado que há bons gestores de fundos - demonstrado pela persistência de sua performance. nos EUA, principalmente entre venture capitalists, mas também em buy outs. A performance dos general partners que levantaram fundos em seqüência é relacionada à performance dos fundos anteriormente levantados por esse gestor.

\subsection{Seleção de Gestores}

Não é difícil concluir que a seleção e avaliação de gestores seja o primeiro e fundamental passo do processo de investimento em um Fundo de venture capital. Devem-se considerar variáveis quantitativas como a performance histórica e qualitativas como a qualidade do time do gestor. Vários critérios podem ser utilizados nesse processo. Alguns deles são descritos a seguir:

- Performance Histórica: o track record é essencial para avaliar a competência do gestor com investimentos em PE/NC. Nem sempre, no Brasil, serão encontrados Fundos com o track record do ciclo completo de PENC. A indústria é nova. O investidor deve examinar, nesse caso, a performance das empresas do portfolio, o grau de satisfação do empresário com o gestor. as práticas de monitoramento, os programas de investimento das empresas e as estratégias de saída.

- Avaliação da Equipe do Gestor: avaliar riscos de comportamento oportunista por parte do gestor. Qualificar o relacionamento desenvolvido com o investidor (lealdade) e com as empresas do portfolio dos fundos geridos pela equipe.

- Características da Organização do Gestor: o foco do gestor está no retorno sobre o investimento ou na taxa de administração? Claramente o foco deve ser o retorno sobre o investimento com a ótica de longo prazo. Observar a natureza da J-Curve dos investimentos nas empresas do portfolio, a idade do Fundo e sua tese do investimento.

- Tamanho: o tamanho da estrutura do gestor é propício à gestāo ativa dos recursos investidos? O investimento específico do cliente é importante no portfolio de clientes desse gestor?

- Atitude Empreendedora: o gestor tem a agilidade necessária? Qual o perfil e grau de inovação percebidos dos integrantes do time de profissionais do gestor? Como funciona o sistema de remuneração desses profissionais?

- Tipo de Organizaçāo: a organizaçāo é pequena e independente ou faz parte de um time maior? O gestor administra produtos que podem ser conflitantes (exemplo: mezzanine e private equity)?

\subsection{Formação e Operação do Fundo}

As seguintes questôes precisam estar adequadamente dimensionadas no prospecto de criação do Fundo:

1. Tamanho do Fundo: limites máximos e mínimos devem ser estabelecidos. Essa é uma questāo fortemente ligada à comercialização do Fundo e pode ser flexibilizada de acordo com a vontade dos investidores e gestores. O tamanho 
do Fundo é importante para garantir que os gestores atuem dentro de limites nos quais eles possuem competência. O crescimento exagerado do número de fundos levantados pelo gestor, por exemplo, pode levar o gestor a atuar em mercados nos quais ele não possui expertise. Nos Estados Unidos, os limites superiores têm sido importantes. uma vez que os Fundos cresceram substancialmente nos anos $90 \mathrm{com}$ o aumento do apetite dos investidores para esse tipo de investimento:

2. Número de Investidores: esse tópico ainda não foi objeto de regulamentaçāo específica no Brasil. Nos Estados Unidos, para que os Fundos possam ter mais de 99 investidores e manter o status de limited partnership eles devem buscar investidores qualificados. Nesse caso, percebe-se, claramente, a preocupação dos órgãos reguladores (no caso a SEC tratando do Investment Company Act de 1940) em não permitir que o investimento em Fundos de PE/NC se torne uma forma disfarçada de distribuição pública, ou seja, exige-se que a partir de um certo número de investidores a sua qualificação seja requisito sine qua non. O ponto importante dessa observação refere-se à necessidade, do ponto de vista do órgão regulador, de garantir que os investidores que participem desse tipo de sociedade possuam conhecimento adequado do tipo de risco ao qual estão expostos:

3. Limitações aos usos do Capital: normalmente podem ser observados limites explícitos à utilização dos recursos investidos. Um limite muito comum refere-se ao montante que pode ser investido em uma única empresa. Esses limites (da ordem de 10 a $20 \%$ do total investido) visam garantir uma diversificação adequada da Carteira do Fundo. Outros Fundos apresentam limites setoriais (montante que pode ser investido em um único setor) ou mesmo geográfico (montante que pode ser investido em um dado país e/ou regiăo). Esses limites são importantes e garantem que os gestores mantenham uma estratégia condizente com o objetivo do Fundo. Não são recomendados limites mínimos de investimento (pelo menos 30\% dos recursos devem ser investidos em telecomunicaçōes. por exemplo) porque esses limites engessam a capacidade do gestor e o obriga a realizar investimentos pelas razões erradas;

4. Prazo do Investimento: os investimentos em private equity, venture capital e buyout tendem a apresentar prazos de maturação diferenciados. No entanto, seja no investimento em private equity (com um capital de mais longo prazo) seja no investimento em venture capital (prazos menores) esses prazos devem estar adequadamente dimensionados na criação do Fundo. Os prazos de 10 anos parecem ser o padrão da indústria. Extensōes, no entanto, podem ocorrer para que os gestores possam ser capazes de extrair todo o potencial dos investimentos realizados. As regras para a aprovação dessas extensōes variam muito de Fundo para Fundo mas precisam estar claras nos contratos estabelecidos. O horizonte temporal é estabelecido para disciplinar a açāo dos gestores que devem procurar firmas com prazos de maturaçāo e saída do investimento adequados ao horizonte temporal do Fundo. Por outro lado, os investidores precisam ter uma visão final do resultado do investimento realizado. O termo para o fim dos investimentos também permite que os investidores possam terminar a sua relação com um gestor que não se mostrar adequado em termos de performance. Como a transferência da gestão de um Fundo para outro é uma ação não recomendável, o prazo previsto para o fim das atividades do Fundo acaba servindo como uma cláusula de limitação da relação entre investidores e gestores. O período de investimento, naturalmente, é inferior ao termo do Fundo e situa-se em torno de 5 anos;

5. Reinvestimento do Capital: os investidores têm interesse em limitar a uma única vez o investimento dos recursos pelos gestores do Fundo. Isso decorre, como discutido anteriormente, do desejo dos investidores de garantir que pelo menos parte dos investimentos do Fundo estariam liquidados ao fim de seu termo. No entanto, os reinvestimento sāo possíveis em muitos casos. O reinvestimento pode ser desejável quando os gestores obtiverem retornos positivos de forma inesperadamente rápida. Dessa forma, se ainda dentro do período de investimento, os investidores podem preferir uma nova 'rodada' de investimentos. Outro aspecto importante para a decisão de permitir o reinvestimento é a prática comum no mercado de PENC de calcular a taxa de administração sobre o capital comprometido. Dessa forma, os gestores acabam investindo um montante de recursos bastante inferior ao aportado pelos investidores. Para corrigir esse problema na base do capital investido, os investidores podem desejar que os gestores tenham a opção de reinvestir os recursos. Esse reinvestimento é, normalmente, permitido até que o montante de capital realmente investido alcance uma certa relaçăo com o capital compromissado. Essa relação, normalmente, situa-se em torno de 100 a $125 \%$ do capital compromissado do Fundo. Alguns Fundos estão estruturados de forma que no caso de saídas de um dado investimento, somente a parcela correspondente ao custo do investimento pode ser reinvestida. A parcela relativa ao lucro deve ser devolvida aos investidores. $O$ oposto, apesar de menos comum, também pode acontecer;

6. Bridge Finance: somente pode ser realizado se estiver previsto e visa facilitar a conclusão de transações de forma mais direta. Essa atividade é normalmente restrita no tempo que pode ser estabelecida;

7. Políticas de Oversubscription: os gestores dos Fundos de PENC, nos Estados Unidos, enfrentam uma demanda maior por suas atividades do que eles sāo capazes de atender, ou seja, a demanda por investimentos em PENC superava a oferta. Assim, é necessário que sejam estabelecidas regras claras de açāo nesse tipo de situação que pode parecer exótica no mercado brasileiro: 
8. Duração do período de Captação de Recursos: esse período, normalmente, não é superior a doze meses como um requisito de justiça em relação aos primeiros investidores. Normalmente, os novos investidores devem contribuir com sua parcela pro rata dos novos investimentos bem como os juros incorridos;

9. Criação de novos Fundos: normalmente é estabelecido um período dentro do qual os gestores não podem realizar novas captaçōes para fomentar negócios adicionais. Essa característica visa manter a atenção dos gestores nos negócios já comprometidos;

10. Agent fees: com o crescimento da indústria de private equity, muitos gestores contrataram empresas profissionais para realizar a distribuição e financiamento do Fundo. Esses agentes são especialmente importantes para empresas que estão começando e ainda não são adequadamente conhecidas pelo mercado. Normalmente, os gestores sāo responsáveis pelo pagamento dessas taxas que não devem recair sobre os investidores que não tiveram valor nenhum agregado com essa atividade. Essa taxa é normalmente descontada da taxa de administração (management fee) do gestor;

11. Contribuição do Gestor para o Fundo: para alinhar ainda mais os interesses dos gestores com os dos investidores, os gestores normalmente participam com pelo menos $1 \%$ do capital do Fundo constituído. No Estados Unidos. essa definição possui impacto tributário (pois torna o gestor um investidor e não um empregado). No entanto, ela parece ser importante mesmo na ausência dessa definição jurídica como instrumento de alinhamento do interesse dos gestores com a organização.

\subsection{Taxas (Fees) e Participação nos Resultados}

Conforme discutido anteriormente, o alinhamento dos interesses dos gestores e dos investidores está no cerne do sucesso potencial de um investimento em PE/NC. Dessa forma, para que o negócio caminhe conforme planejado, os gestores precisam ser remunerados de modo que haja um balanço entre seus interesses e os dos investidores. A questão da remuneraçāo dos gestores pode ser facilmente apontada como a mais polêmica do setor de PENC.

Os gestores recebem uma taxa de administração que é designada para cobrir as despesas administrativas do negócio e remunerar a equipe de analistas. Essa taxa é calculada como um percentual (normalmente entre 2 e $3 \%$ ) do capital comprometido para o Fundo e paga em bases periódicas antecipadas (trimestralmente, semestralmente ou anualmente). Fundos maiores pagam taxas de administração menores porque as despesas de gestāo do Fundo não são proporcionais ao montante de capital investido. Adicionalmente, os gestores recebem, normalmente, $20 \%$ do lucro auferido, ao final dos investimentos. É importante ressaltar que esse lucro deve ser calculado pela média dos investimentos realizados pelo Fundo e não individualmente. Uma grande controvérsia existe entre a proporção da remuneração dos gestores que deve ser composta pela taxa de administração e aquela correspondente à distribuição dos resultados.

A solução balanceada para esse tipo de conflito é fundamental para o bom funcionamento do Fundo. Os investidores argumentam que a taxa de administração não deve ser significativa e que os gestores não devem, por exemplo, ser capazes de enriquecer com os montantes pagos a título de taxa de administração. Isso porque eles devem direcionar seus esforços para produzir retornos que possam ser divididos com os investidores, ou seja, o principal componente da remuneração dos gestores deveria estar relacionado com a distribuição do resultado. Essa abordagem é a adequada à medida que alinha de forma mais direta os interesses de gestores e investidores.

A taxa de administração é reduzida com o passar do tempo à medida que os fundos saem de suas participações e investimentos. Adicionalmente, essa taxa está normalmente baseada no capital comprometido e não naquele realmente investido. $\mathrm{O}$ incentivo do gestor para que os recursos sejam realmente investidos está somente ligado à distribuição do resultado ao final do investimento.

Muitas vezes, os gestores estão administrando mais de um Fundo. Nesses casos tem-se o problema de que o gestor pode acabar recebendo montantes desproporcionalmente elevados somente por intermédio da taxa de administração. Assim. é recomendável que a taxa de administração caia com o aumento do número de Fundos administrados pelo gestor. Isso pode ser operacionalizado pela redução da taxa de administração com o passar do tempo uma vez que o desinvestimento e a participação dos gestores em outros Fundos tende a ocorrer com o tempo.

Nos EUA, o intervalo de variação das taxas de administração é pequeno como será visto a seguir. Recomenda-se que a taxa tenda, com a passagem do período de investimento, a incidir sobre o capital investido e não comprometido. Isso elimina a hipótese de os gestores adotarem uma postura inerte no que se refere aos novos investimentos.

A principal crítica dessa abordagem é que os gestores terão incentivos para realizar investimentos sem a devida diligência. Sugere-se, então, que a taxa de administraçāo tenha seus valores absolutos reduzidos, deixando a 'parte do leāo da remuneração' dos gestores para a distribuiçăo do resultado. Isso forçaria uma atitude mais proativa dos gestores que teriam 'pressa' em realizar os investimentos como os investidores querem. No entanto, o grosso de sua remuneração estará ligado ao resultado final do investimento. No que se refere às rendas extras que podem ser recebidas pelos Fundos (investment banking fee, break-up fee. monitoring fee. consulting fee) os investidores conseguiram participar de pelo menos $50 \%$ delas, no mercado americano. Essa participaçāo visa, essencialmente, reduzir os incentivos de os gestores participarem em outras atividades. 
No que se refere à participação nos resultados (carried interest). o padrão da indústria continua a ser de $20 \%$ em termos internacionais. A grande polêmica, nesse aspecto, refere-se à base do cálculo. Alguns Fundos devolvem as despesas diversas cobradas para recompor a base de cálculo outros năo. Outro aspecto relevante refere-se ao indexador sobre o qual os resultados devem ser calculados (preferred returns). Assim, alguns Fundos pagam taxas mais atrativas aos gestores somente se os retornos superarem algum benchmark preestabelecido. Acredita-se que as práticas relacionadas com a superação de um benchmark apresentem melhor alinhamento dos interesses dos vários participantes dos fundos.

Conforme citado anteriormente, pesquisas recentes (LJUNGQVIST. 2003) apresentam evidências empíricas que os investimentos em PE/NC produzem resultados com prêmios sobre o índice de mercado de capitais da ordem de 5 a $8 \%$. Esse é o objetivo básico do investimento nesse tipo de ativo alternativo. Assim, é razoável supor que os gestores sejam remunerados por uma taxa que incida sobre o percentual da remuneração do investimento que supere o benchmark. Do ponto de vista técnico, essa é a melhor alternativa de organização dos investimentos e remuneração.

É clássico o trabalho de Gompers e Lerner (1999) a respeito das duas parcelas de remuneração dos gestores: a taxa de administraçăo e o percentual de ganho de capital recebido pelos gestores após o pagamento da remuneração mínima requerida pelos investidores (carried interest).

Esta pesquisa é interessante por incluir apenas gestores de Fundos de venture capital (419 partnerships) que foram levantados (first closing) entre 1978 e 1992, ou seja, na segunda e terceira décadas da indústria norte-americana de venture capital.

O tamanho médio dos Fundos da amostra é de U\$62.7 milhões e os resultados indicam uma variação muito grande no valor presente do fluxo das taxas de administração pagas ao longo da vida do Fundo como percentual do capital comprometido: no caso de gestores de grande porte, o percentual é de $15,1 \%$, enquanto nas pequenas organizações o percentual atinge $19,9 \%$, contra $18,2 \%$ nas de porte médio.

Constata-se, também, que no caso de gestores cujos investimentos se concentraram em empresas de alta tecnologia ou empresas emergentes (early stage), esse percentual se situou em torno de $19 \%$ do capital comprometido.

Num estudo mais recente, constatou-se que os Fundos de pequeno porte, com capital comprometido da ordem de U\$ 1 a U\$ 50 milhões, trabalhavam com taxas de administraçāo que, em média, se situavam em $2,5 \%$ sobre o capital comprometido no caso de private equity (e.g. buy out funds), e 2,3\% no caso dos Fundos de venture capital, no período 1995-2000. (LERNER, 2001).

No período amostral de 1978 a 1992, verificou-se que o percentual dos ganhos de capital (carried interests) sobre o capital comprometido mostrou grande estabilidade entre 20 e $21 \%$ independentemente do porte do gestor, de ser ou não o primeiro Fundo, do foco dos investimentos e da idade da organização gestora. Num segundo estudo, que abrange o período de 1995 a 2000, o percentual médio de participação sobre ganhos de capital elevou-se em função do porte do Fundo, de $20 \%$ para os pequenos até, em média $23,5 \%$ para os de porte superior a US $\$ 500$ milhões. (op cit., 2001).

Um aspecto que o estudo ressalta é o valor da reputação: ele é importante motivador para organizações na sua primeira fase. Há evidência de que a remuneração dos gestores mais maduros é mais sensível ao seu desempenho passado. Gestores mais maduros recebem menor parcela de seu ganho por meio da taxa de administração.

Talvez a principal questão de governança no relacionamento entre gestores e investidores em cotas dos Fundos de PE/NC esteja ligada à forma de atuação do comitê de investimentos.

Entende-se que a forma de atuação mais adequada seja aquela na qual os gestores possuem papel proativo enquanto os investidores possuem direito de veto em alguns aspectos associados a cláusulas claras de proteção. Essa foi observada como a prática mais comum entre os grandes participantes internacionais nesse mercado. Por outro lado, o comitê consultivo (advisory board), que não opina sobre as decisões de investimento, deve ser composto, basicamente, pelos investidores e versar sobre questōes como a aprovação da reavaliação/impairment das Carteiras, conflitos de interesse gerados, extensões do Fundo dentre outras funçōes.

\section{CONCLUSÕES}

Pode-se apontar alguns pontos-chave da indústria de private equity e venture capital para os investidores institucionais, especialmente entidades de previdência complementar (EFPC). Inicialmente, esses investimentos apresentam, indubitavelmente, excelentes oportunidades de diversificação e conseqüente melhora no perfil risco/retorno dessas instituições. No entanto, a forma de alocar esses investimentos não pode ser a tradicional, baseada nos conceitos de análise de média-variância.

Dadas as características desses ativos, é necessário que processos de simulação intertemporal sejam usados de forma a contextualizar os investimentos realizados nos termos do modelo de asset liability management da instituição. Esse aspecto é fundamental para que o processo de alocação seja bem sucedido.

Adicionalmente, os investimentos devem sempre ser pautados por boas práticas de governança e gestão. Deve-se, sempre, lembrar que os investimentos em PE/VC possuem resultados potenciais justamente pela quebra de assimetria in- 
formacional realizada nos investimentos privados e no potencial de mitigar conflitos de agência importantes, ou seja, se a estrutura de PENC possuir conflitos de gestāo muito sérios os mesmos problemas comuns em investimentos tradicionais voltarāo a ocorrer. Assim, a performance do investimento deve sempre ser focada como principal critério de remuneração e gestão desses investimentos.

Como resultado da pesquisa de campo e das entrevistas com os gestores das EFPCs, podem ser apontados os problemas: (a) do alto custo de monitoramento percebido; (b) falta de padronizaçăo dos contratos; (c) taxas de administraçăo pretendidas e (d) indefinição sobre o modelo de governança do fundo de PENC no que tange à relação e as responsabilidades da EFPC na determinação da política de investimento do Fundo como principais obstáculos à maior participação dos ativos de PENC nas Carteiras de Investimento das EFPCs. No momento, as altas taxas de juros ainda constituem grande obstáculo percebido.

Alguns sugeriram, inclusive, que fossem conduzidas pesquisas aplicadas para apoiar a criação de modelos e melhores práticas de governança dos Fundos de PE/NC.

Os fund-of-funds foram apontados como alternativa interessante, de modo a reduzir os custos de monitoramento por parte das EFPCS. Não parece, ainda, existir uma política homogênea no que se refere aos montantes e percentuais da Carteira que devem ser investidos, havendo espaço para maiores desenvolvimentos principalmente ligando o montante de investimento ao processo de asset liability management (ALM) das entidades com enfoque dinâmico de longo prazo.

Apesar desses aspectos, existe interesse considerável dos gestores das EFPC em conhecer e explorar mais a fundo as potencialidades dos investimentos em PE/NC. Os entrevistados pareceram concordar que o momento da economia brasileira é propício para aprofundar o conhecimento e a forma de gerir investimentos nas Carteiras.

A potencial redução da atratividade dos investimentos em títulos públicos advinda das menores taxas reais de juros e mesmo a tendência a reduzir-se esse tipo de ativo no total da riqueza financeira do país, é tendência que leva os gestores a procurarem alternativas para melhorar a relação risco-retorno de suas Carteiras.

\section{Referências Bibliográficas}

BARGER, T.. How to be a Vigilant Fund Investor. Seminário Internacional, International Finance Corporation, Rio de Janeiro, 2004.

BLAYDON, C;; HORVATH, M.. What's a company worth? It depends of which GP you ask. Venture Capital Journal, May, 40-41, 2002.

; WAINWRIGHT, F.. The year of valuation guidelines. The Private Equity Annual Review 2002, Private Equity International, 2003.

CVM. Instruções 391/03 e 209/94 - www.cvm.gov.br.

COCHRANE, J.. The risk and return of venture capital. Journal of Financial Economics, v.75, n.1, p.3-52, 2005.

DELANEY, P. R.; ADLER, J. R.; EPSTEINS, B. J.; FORAN, M. F.. GAAP 99: Interpretation and Application of Generally Accepted Accounting Principles 1999. New York: John Wiley \& Sons, Inc., 1999.

FINANCIAL ACCOUNTING STANDARDS BOARD. The IASC-U.S. Comparison project: a report on the Similarities and Differences between IASC Standards and U.S. GAAP. Connecticut, FASB, 1996.

GOMES, A.. Going Public without Governance: Managerial Reputation Effects. Journal of Finance, Vol. 55, No 2, April, 2000.

GOMPERS, P. A. Grandstanding in the Venture Capital Industry. Journal of Financial Economics 43, 133-156, 1996.

; LERNER, J.. The use of covenants: An analysis of venture partnership agreements. Journal of Law and Economics 39, 463-498, 1996:

Risk and reward in private equity investments: the challenge of performance assessment. The Journal of Private Equity, Winter 5-12, 1997.

The Venture Capital Cycle, Capítulo 4. MIT Press, 1999.

JONES, C. M.; RHODES-KROPF, M.. The price of diversifiable risk in venture capital and private equity. Working paper, Columbia University, 2004.

KAPLAN, S.; SCHOAR, A.. Private Equity Performance: Returns, Persistence and Capital. Forthcoming: Journal of Finance, August 2005.

LERNER, J.. A Note on Private Equity Partnership Agreements. Harvard Business School, Mar 2001.

LOPES, A. B.. A Informação Contábil e o Mercado de Capitais. Thomson Pioneira, São Paulo, 2002.

; LIMA, I. S.. Contabilidade e Controle de Operaçōes com Derivativos. 2a. ed., Thomson Pioneira, São Paulo, 2003.

LJUNGQVIST, A.; RICHARDSON, M.. The Cash Flow, return and risk characteristics of private equity. Working paper, Stern School of Business - New York University, 2003.

MOSKOWITZ, T.; VISSING-JORGENSES, A.. The returns to entrepreneurial investment: a private equity premium puzzle? American Economic Review 92, 745-778, 2002.

MULVEY, J.. Multi-Stage Stochastic Optimization Models for Long-Term Investors. Quantitative Analysis in Financial Markets, v.3, p.66-85, 2001. 
A Surplus Optimization Perspective. Investment Management Review 3, 31-89, 1989.

PAVANI, C.. O Capital de Risco no Brasil - Conceitos Evolução e Perspectivas. E-papers, Rio de Janeiro, 2003.

PELLON, J. M.; RAMON, M. B. The Determinants of Private Equity Fundraising in Western Europe. (April 2001). EFMA 2001 Lugano Meetings. http://ssrn.com/abstract=269789.

Conceptual Model for Private Equity Markets: Proposal and Empirical Test on Fundraising. EFMA 2002 London Meetings. http://ssrn.com/abstract=313934.

QUIGLEY, J. M.; WOODWARD, S.. Benchmarking the Returns to Venture. NBER Working Paper 10202, December 2003.

SWENSEN, D. F. Pioneering portfolio management: an unconventional approach to institutional investment. The Free Press, New York, 2000.

WEIDIG, T; MATHONET, P.. The risk profiles of private equity. SSRN Working paper, <http://ssrn.com/abstract=495482>, 2004.

WILKIE, A. Stochastic Investment Models: Theory and Applications. Insurance: Mathematics and Economics, 6, 65-83, 1987.

\section{NOTA - Endereço dos autores}

Universidade de São Paulo

Faculdade de Economia, Administração e Contabilidade

Departamento de Contabilidade e Atuária

Av. Prof. Luciano Gualberto, 908 - Cidade Universitária

São Paulo - SP

05508-900
Fundação Getúlio Vargas

Escola de Administraçâo de Empresas

Av. 9 de Julho, 2029 - Bela Vista

São Paulo - SP

01313-902 


\section{ANEXO I}

Tabela A.1 e A.2 - Correlaçōes do Invest. em Private Equity com Ativos Tradicionais

Tabela 5.3 Historical Correlation Matrix Provides a Starting Point for Defining the Relationship Between Assets Classes

\begin{tabular}{|l|c|c|c|c|c|c|c|c}
\hline & $\begin{array}{c}\text { U.S. } \\
\text { Equity } \\
\text { U.S. Equity }\end{array}$ & $\begin{array}{c}\text { U.S. } \\
\text { bonds }\end{array}$ & $\begin{array}{c}\text { Developed } \\
\text { equity }\end{array}$ & $\begin{array}{c}\text { Emerging } \\
\text { equity }\end{array}$ & $\begin{array}{c}\text { Absolute } \\
\text { return }\end{array}$ & $\begin{array}{c}\text { Private } \\
\text { Equity }\end{array}$ & $\begin{array}{c}\text { Real } \\
\text { estate }\end{array}$ & Cash \\
\hline U.S. bonds &, 06 & 1,00 & & & & & & \\
\hline Developed equity &, 48 &, 25 & 1,00 & & & & & \\
\hline Emerging equity &, 14 &, 04 &, 35 & 1,00 & & & & \\
\hline Absolute return &, 28 &, 15 &, 15 &, 36 & 1,00 & & & \\
\hline Private Equity &, 30 & $(, 17)$ &, 19 & $(, 13)$ &, 29 & 1,00 & & \\
\hline Real estate &, 13 &, 03 &, 30 & $(, 21)$ &, 06 &, 08 & 1,00 & \\
\hline Cash & $(, 09)$ &, 70 &, 08 & $(, 56)$ & $(, 08)$ &, 01 &, 35 & 1,00 \\
\hline
\end{tabular}

Sources1: U.S. equity: 70 percent weight on the S \& P 500 (1929-1997)plus 30 percent weight on the Russel 2000 (1979-1997) or the DFA Small Companies Deciles 6 - 10 (1926-1978).U.S. bonds: Lehman Brothers GovernamentBond Index (1973-1997) and Ibbotson Intermediate Term Governament Bond Index (1926-1972). Developed equity: Capital International data (1960-1977) and Adjusted MSCI-GDPEAFE Index (1978-1997). Emerging Equity: IFC Emerging Market Index (1985-19997). Absolut Return: Yale Absolut Return Portfolio (1991-1997), Weighted Average Composite of Cambridge Associates' Data and other reported returns for Absolut Return Managers (1978-1990).Private equity: Yale Private Equity Portfolio (1982-1997). Real estate: NCREIF FRC Index (1977-1997).

Fonte 2: Swensen, 2000

Tabela 5.4 Modified Correlation Matrix Assumptions About Future Interrelationships

\begin{tabular}{l|c|c|c|c|c|c|c|c}
\hline & $\begin{array}{c}\text { U.S. } \\
\text { Equity } \\
1,00\end{array}$ & $\begin{array}{c}\text { U.S. } \\
\text { bonds }\end{array}$ & $\begin{array}{c}\text { Developed } \\
\text { equity }\end{array}$ & $\begin{array}{c}\text { Emerging } \\
\text { equity }\end{array}$ & $\begin{array}{c}\text { Absolute } \\
\text { return }\end{array}$ & $\begin{array}{c}\text { Private } \\
\text { Equity }\end{array}$ & $\begin{array}{c}\text { Real } \\
\text { estate }\end{array}$ & Cash \\
\hline U.S. bonds &, 45 & 1,00 & & & & & & \\
\hline Developed equity &, 60 &, 30 & 1,00 & & & & & \\
\hline Emerging equity &, 30 &, 20 &, 50 & 1,00 & & & & \\
\hline Absolute return &, 30 &, 35 &, 30 &, 30 & 1,00 & & & \\
\hline Private Equity &, 40 &, 25 &, 25 &, 10 &, 25 & 1,00 & & \\
\hline Real estate &, 15 &, 25 &, 20 &, 10 &, 40 &, 15 & 1,00 & \\
\hline Cash &, 00 &, 50 &, 00 &, 00 &, 00 &, 00 &, 20 & 1,00 \\
\hline
\end{tabular}

Sources 1: Yale University Investments Office 